\title{
Comparison between non-parametric indexes in the selection of biofortified curly lettuce
}

\begin{abstract}
Joicy Vitória Miranda Peixoto'*(D, Gabriel Mascarenhas Maciel²D, Ana Carolina Silva Siquieroli²(D,

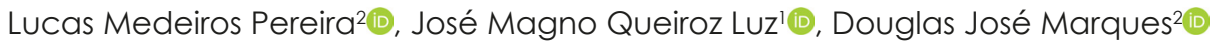

'Federal University of Uberlândia, Uberlândia, Brazil

${ }^{2}$ Federal University of Uberlândia, Monte Carmelo, Brazil

*Corresponding author, e-mail: joicyvmpeixoto@ufu.br

\begin{abstract}
Selection indexes can be applied to simultaneous analysis of traits, increasing the efficiency of breeding in choosing the genotypes that meet the needs of both the market and the consumer. While it is a technic applied to several cultures, there are few studies about it in lettuce lines. For this reason, the aim of this study was to comparate assess the efficiency of different selection indexes for selecting biofortifiedleaf lettuce lines with good agronomic traits. The experiment was carried out at the Estação Experimental de Hortaliças of Federal University of Uberlândia (UFU), campus Monte Carmelo, in 2018. The experiment was designed in full randomized blocks of 3 repetitions with 25 leaf lettuce genotypes (22 lines from cultivars Pira 72 versus Uberlândia 10000 and 3 commercial cultivars - cv. Grand Rapids, UFU-Biofort and Uberlândia 10000). The lines are part of the UFU biofortified lettuce breeding program and were assessed for the total green mass $(\mathrm{g})$, the stem diameter $(\mathrm{cm})$, commercial leaves count, plant diameter $(\mathrm{cm})$, foliar temperature $\left({ }^{\circ} \mathrm{C}\right)$, SPAD index, anthocyanin content $(\mathrm{mg}$ $100 \mathrm{~g}^{-1}$ sample), and bolting (days after sowing). To estimate selection gains, 10 genotypes were selected using both direct and indirect selection, as well as the traditional index, the sum of ranks index, Willians base index, and the multiplicative index. Mulamba and Mock sum of ranks index and Subandi multiplicative index provided the biggest total gains for the traits assessed in biofortified leaf lettuce. Both indexes were similar in selecting genotypes.
\end{abstract}

Keywords: biofortified foods, Lactuca sativa L., selection gains, selection indexes

\section{Introduction}

The lettuce (Lactuca sativa L.) is the most consumed leafy vegetable in Brazil and worldwide. Per capita consumption of lettuce salad is lower only than that of potatoes (Brzezinski et al., 2017; Kim et al., 2018). Leaf lettuce (Lactuca sativa, var. crispa) is economically more important when compared to the iceberg, butterhead, and romaine ones (Sala \& Costa, 2012; Kim et al., 2018).

Lettuce is a rich source of nutrients such as carotenoids, ascorbic acid, and phenolic compounds (López et al., 2014). Carotenoids help to prevent several diseases related to the oxidative stress. In addition, they are vitamin A precursors (Rocha \& Reed, 2014; Cassetari et al., 2015). The changing in population eating habits, and the search for a healthful diet and a better quality of life directly affect the market demand for a better nutrition quality lettuce.

Few researches have been conducted into the biofortified lettuce (Cassetari et al., 2015; Jacinto et al., 2019; Silveira et al., 2019; Sousa et al., 2019). One of the main obstacles is to feasibly get an individual with both good agronomic traits and high level of carotenoids (Maciel et al., 2019a). Overall, the selection of lettuce lines has been done by univariate analysis (Son \& Oh, 2013; Resende et al., 2017; Tezza \& Minuzzi, 2019), and the product was superior in only one or few traits. With such limitation, it is necessary to appraise possible improving methodologies capable increase the efficiency in genetic selection. Alternatively, one possibility to increase the success chance in breeding programs is to make simultaneous selection of some traits with economic relevance, applying selection indexes (Vasconcelos et al., 2010; Terres et al., 2015; Bizari et al., 2017; Tassone et al., 2019). These indexes can enable the optimal linear combination within a set of information from the experimental unit, and, therefore, the efficient 
simultaneous selection of traits (Cruz et al., 2014).

Nonparametric indexes may help to select lettuce lines that combine good agronomic traits with a better nutrition quality. Many pieces of research confirm the efficiency of applying such indexes to the selection of superior individuals from breeding programs (Terres et al., 2015; Bizari et al., 2017; Vieira et al., 2017), except for lettuce. For this reason, the aim of this study was to comparate assess the efficiency of different selection indexes for selecting biofortified leaf lettuce lines with good agronomic traits.

\section{Material and Methods}

The experiment was conducted at the Vegetable Experimental Station at the Federal University of Uberlândia-UFU, Monte Carmelo campus (1842' 43.19"S: 47029'55.8"W; 873 meters above sea level), in 2018. The temperature during the experiment ranged from 16.23 ${ }^{\circ} \mathrm{C}$ minimum and $27.49{ }^{\circ} \mathrm{C}$ maximum, with an average relative humidity of $75.47 \%$ and average precipitation of $1.27 \mathrm{~mm}$.

The study covered 22 lettuce lines, obtained by pedigree method. These lines were obtained through hybridization performed between cultivars Pira 72 and Uberlândia 10000 (rich in carotenoids) (Souza et al., 2008), after six successive self-pollination procedures, from 2013 to 2017. The lines are part of the UFU biofortified lettuce breeding program, and all genealogy was stored in the software "BG a BIOFORT" INPI patent number BR512019002403-6 (Maciel et al., 2019b). Three following cultivars were used as control: cv. Grand Rapids, UFUBiofort and Uberlândia 10000 (Souza et al., 2008), totaling 25 treatments.

Sowing was carried out on March 28th, 2018. The seedlings were grown in 200-cell EPS trays with commercial coconut fiber substrate. After sowing, the trays were placed in a $5 \mathrm{~m} \times 6 \mathrm{~m}$, arch-type greenhouse, built with $3.5 \mathrm{~m}$ ceiling, and covered with UV-resistant, 150-micron transparent polyethylene film and side curtains of white, anti-aphid screen. Lettuce seedlings were transplanted to definitive field seedbeds 29 days after sowing. Seedbeds were $1.30 \mathrm{~m}$ long and were tilled using a rototiller.

The experiment soil showed the following features: $\mathrm{pH}\left(\mathrm{H}_{2} \mathrm{O}\right)=5.9$; available $\mathrm{P}=30.1 \mathrm{mg} \mathrm{dm}^{-3} ; \mathrm{K}=0.22 \mathrm{cmolc}$ $\mathrm{dm}^{-3} ; \mathrm{Ca}=2.8 \mathrm{cmolc} \mathrm{dm}^{-3} ; \mathrm{Mg}^{-}=1.0 \mathrm{cmolc} \mathrm{dm}^{-3} ; \mathrm{H}^{+}$

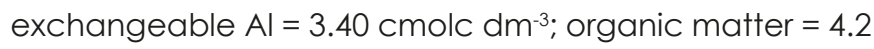

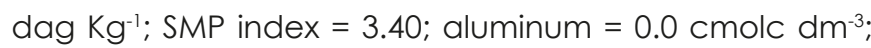
CEC pH $7.0=7.42 \mathrm{cmolc} \mathrm{dm}^{-3}$; CEC pH 7.0 base saturation = 54\%; effective CEC aluminum saturation $=0 \%$; copper $=$ $2.3 \mathrm{mg} \mathrm{dm}^{-3} ;$ zinc $=6.6 \mathrm{mg} \mathrm{dm}^{-3}$; and manganese $=6.6 \mathrm{mg}$ $\mathrm{dm}^{-3}$. The handling followed the procedures for lettuce culture (Filgueira, 2013).

The plots of the experiment comprised 16 plants, which were distributed in four rows per seedbed distant $0.25 \mathrm{~m} \times 0.25 \mathrm{~m}$ from each other. The eight middle plants of each plot were assessed. The plants were harvested 35 days after transplanting, and were assessed for total green mass (g), stem diameter (cm), leaves count, plant diameter $(\mathrm{cm})$, foliar temperature $\left({ }^{\circ} \mathrm{C}\right)$, soil plant analysis development (SPAD) index, anthocyanin content (mg $100 \mathrm{~g}^{-1}$ sample), and bolting (days after sowing).

\section{Traits Assessed}

The total green mass (GM) was assessed by weighing all the outer leaves. Stem diameter (SD) was calculated with calipers. Commercial leaves count (LC) was assessed by counting the number of leaves longer than $5 \mathrm{~cm}$. Plant diameter (PD) was calculated in centimeters, with the aid of a graduated ruler. The measurement was performed from one edge of the plant to the other. Foliar temperature (FT) was measured with an infrared thermometer (model 4000.4GL, Everest Interscience, Tucson, AZ, USA) by pointing the device sensor to the central part of foliar surface of the sampled outer leaves.

The total of anthocyanin content (ANT) was calculated using Francis (1982) method. The concentration of anthocyanin pigments was determined by absorbance, according to the equation:

$$
A t=\frac{(A b s * f)}{\varepsilon},
$$

where: $A t=$ anthocyanins (mg of anthocyanin $100 \mathrm{~g}^{-1}$ of fresh mass); Abs = absorbance; $f$ = dilution factor; $\varepsilon=$ molar attenuation coefficient of cyanidin (98.2).

The SPAD index (Cassetari et al., 2015) was calculated by the mean value of the data from the four central plants of each plot. The hand-held chlorophyll meter model Minolta SPAD-502 CFL1030 was used. The days until the flower stalk appeared were also assessed (plant bolting was counted in days from sowing - EB).

\section{Statistical analysis}

The experiment was designed in full randomized blocks of 3 repetitions. The analysis of variance ( $\mathrm{p}$-value $\leq 0.05$ ) was performed to obtain the trait mean squares (TMS) and the coefficient of variation (CV). The coefficient of genetic variation $(\mathrm{CVg})$, the ratio between the coefficient of genetic variation ( $\mathrm{CVg}$ ) and the coefficient of environmental variation ( $C V e)-C V g / C V e$, and the coefficient of genotypic determination $\left(\mathrm{H}^{2}\right)$ for each variable were also assessed. The $\mathrm{H}^{2}$ was calculated using the following estimator 


$$
H^{2}=\frac{\widehat{\phi} g}{T M S / r} \quad \widehat{\varnothing} g=\left(\frac{T M S-R M S}{r}\right),
$$

where: $H^{2}$ is the coefficient of genotypic determination; $\widehat{\emptyset} g$ is the genetic quadratic component; TMS is the genotype mean square; RMS is the residual mean square; and $r$ is the number of repetitions.

Both the phenotypic (rp) and genotypic (rg) correlations, as well as the selection indexes were determined for the traits which showed significant result in analysis of variance. The phenotypic and genotypic correlations estimators were

$$
r_{p}=\frac{\mathrm{TMP}_{\mathrm{xy}}}{\sqrt{\mathrm{TMS}_{\mathrm{x}}^{*} \mathrm{TMS}_{\mathrm{y}}}} \text { and } \mathrm{r}_{\mathrm{g}}=\frac{\widehat{\sigma}_{\mathrm{gxy}}}{\sqrt{\hat{\sigma}_{\mathrm{gx}}^{2} \mathrm{o}^{*} \widehat{\sigma}_{\mathrm{gy}}^{2}}} \text {, respectively, }
$$

where: TMP is the treatment mean product; TMS is the treatment mean square; $X$ and $Y$ are the traits analyzed; $\widehat{\sigma}_{\mathrm{gxy}}$ is the genotypic covariance estimator between $X$ and $Y$; and $\widehat{\sigma}_{\mathrm{gx}}^{2}$ and $\widehat{\sigma}_{\mathrm{gy}}^{2}$ are the genotypic variances estimators of $X$ and $Y$, respectively (Cruz et al., 2012). The significance of the phenotypic correlation was estimated by the t test ( $p \leq 0.05)$. For genotypic correlation, the booststrap method was applied ( $p \leq 0.05$ ).

To estimate the selection gains, 10 genotypes ( $40 \%$ of genotypes studied) were selected using both the direct and indirect methodologies (Cruz et al., 2012); Smith (1936) and Hazel (1943) traditional selection index (SH); Mulamba \& Mock (1978) sum of ranks index (MM); Willians (1962) base index (W); and the multiplicative index of Subandi et al. (1973). The selection criteria for all selection indexes were to increase GM, SD, LC, SPAD and $\mathrm{EB}$ and to decrease PD. The economic weight comprises the coefficient of genetic variation of each variable, according to Cruz et al. (2012). The software Genes v. 2015.5.0 (Cruz, 2013) was used in the statistical analysis.

The estimate gain via direct selection (Cruz et al., 2012) at the $i$-th trait $\left(G S_{i}\right)$ was denoted by

$$
G S_{i}=\left(X_{s i}-X_{o i}\right) h_{i}^{2}=D S_{i} h_{i}^{2}
$$

where: $X_{s i}$ is the mean of lines selected for $i$ trait; $x_{o i}$ is the original population mean; $D S_{i}$ is the population selection differential; and $h_{i}^{2}$ is the trait $i$ genotypic determination coefficient.

The indirect gain (Cruz et al., 2012) for j trait, by selecting trait $i$, was given by

$$
G S_{j(i)}=D S_{j(i)} h_{i}^{2}
$$

where: $D S_{j(i)}$ is the indirect selection differential from the mean of the individuals' traits whose superiority had been highlighted by another trait to which the direct selection was applied.

The traditional selection index held by Smith (1936) and Hazel (1943) was determined by the linear combination of the traits assessed. It was estimated by the selection index (I) and the aggregate genotype $(H)$ as follows:

$$
\begin{aligned}
& I=b_{1} y_{1}+b_{2} y_{2}+\ldots+b_{n} y_{n}=\sum_{i=1}^{n} b_{i} y_{i}=y^{\prime} b \\
& H=a_{1} g_{1}+a_{2} g_{2}+\ldots+a_{n} g_{n}=\sum_{i=1}^{n} a_{i} g_{i}=g^{\prime} a
\end{aligned}
$$

where: $n$ is the number of traits analyzed; $b$ is the 1xn vector for the weighting factors of the estimated selection index; ${ }^{\prime}$ is the nxp matrix for the traits phenotypic values; $a$ is the $1 \times n$ vector for economic weights previously established; $g$ is the nxp matrix for unknown genetic values of the $n$ traits in question; $p$ is the number of families or progenies analyzed.

The $n \times n$ matrix for phenotypic variances and covariances is represented by $P$. The $n \times n$ matrix for traits genetic covariances is given by $G$. The vector $b$ is estimated by $b=P^{-1} G a$, and $P^{-1}$ is the traits phenotypic variances and covariances inverse matrix. The expected gain for trait $\mathrm{j}$ was calculated by

$$
\Delta g_{j(I)}=D S_{j(I)} h_{j}^{2}
$$

where: $\Delta g_{j(l)}=g_{j(l)}$ is the trait j expected gain, and selection based on index $I ; D S_{j(I)}$ is the trait $\mathrm{j}$ selection differential, and selection based on index l; and $h_{j}^{2}$ is the trait $\mathrm{j}$ heritability.

The sum of ranks index (Mulamba \& Mock, 1978) dispenses with both the genotypic and phenotypic variance and covariance estimates and the economic weights to the traits studied (Cruz et al., 2014). It sorts the genotypes hierarchically by assigning higher absolute values to those with better performance. The process is done for each trait studied. After that, the sort number of each genotype related to each trait studied is added up, giving the selection index as follows:

$$
I=r_{1}+r_{2}+\ldots+r_{n}
$$

where: $I$ is the index value for a given individual or family; $r_{j}$ is the rank of an individual related to the $j$-th variable; and $n$ is the number of variables the index comprises.

According to the breeder's specifications, the method can assign different weights to sort the variables rank. Thus, the economic weights were given by:

$$
I=p_{1} r_{1}+p_{2} r_{2}+\ldots p_{j} r_{n}
$$

where: $p_{j}$ is the economic weight assigned to the j-th trait.

The Willians (1962) base index comprises the linear combination of the traits mean phenotypic values, which are weighted by their respective economic weights. The index is given by:

$I=a_{1} y_{1}+a_{2} y_{2}+\ldots+a_{n} y_{n}=\sum_{i=1}^{n} a_{i} y_{i}=y^{\prime} a$

where: $y$ is the mean; and $a$ is the economic weight for the traits analyzed.

In the multiplicative index (Subandi et al., 
1973), the index is assumed to be directly or inversely proportional to the variable analyzed, according to the breeder's criteria. The index is given by:

$$
I_{E i}=\log \prod_{j=1}^{m}\left(X_{i j}-K_{j}\right)=\log \left[\left(X_{i 1}-K_{1}\right)\left(X_{i 2}-K_{2}\right) \ldots\left(X_{i n}-K_{n}\right)\right] \text {, }
$$

where: $I_{E i}$ is the multiplicative index; $X_{i j}$ is the

mean of the trait $\mathrm{j}$ measured in the genotype $\mathrm{i} ; K_{j}$ is the lowest possible value: $\left[K_{j}=\frac{n\left(\min x_{i j}\right)-\max x x_{i j}}{n-1}\right] ; n$ is the number of genotypes; $\min . X_{i j}$ and $\max . X_{i j}$ are the trait $j$ lowest and highest means, respectively.

Mean, maximum and minimum values of each variable were estimated for the genotype-ideotype distance index (Cruz, 2006). Xij was considered the mean phenotypic value of the i-th genotype related to the j-th trait. Yij is the transformed mean phenotypic value, and $\mathrm{C}$ j is a constant related to the depreciation of the genotype mean. Thus, Llj is the genotype lower limit related to the trait j, LSj is the genotype higher limit, and VOj is the genotype optimal value.

$$
\begin{aligned}
& \text { If } L I j<X i j<L S j \text {, so Yij = Xij; } \\
& \text { If } X i j<L L j, Y i j=X i j+V O j-L I j-C j ; \\
& \text { If } X i j>L S j, Y i j=X i j+V O j-L S j+C j .
\end{aligned}
$$

The methodology considers $\mathrm{Cj}=\mathrm{LSj}$ - Llj. The value $\mathrm{Cj}$ proved that any $\mathrm{Xij}$ within the optimal interval of variation would result in a Yij with magnitude near the optimal value (VOj). The Xij transformation aimed at reducing the phenotypic values outside the interval. The transformed values of Yij were standardized and weighted by the weight assigned to each trait, as follows:

$$
y_{i j}=\sqrt{a_{j}} \frac{y_{i j}}{S\left(y_{j}\right)^{\prime}}
$$

where: $s\left(y_{j}\right)$ is the standard deviation of the transformed mean phenotypic values; and $a_{j}$ is the trait economic weight or value. VOj was standardized and weighted as well, as follows:

$$
V O_{i j}=\sqrt{a_{j}} \frac{V O_{j}}{S\left(y_{j}\right)} .
$$

The values of the genotype-ideotype distance (GID) index were calculated as follows:

$$
I_{D G I}=\sqrt{\frac{1}{n} \sum_{j=1}^{n}\left(y_{i j}-v o_{j}\right)^{2}}
$$

\section{Results and Discussion}

The genotypes of biofortified leaf lettuce showed genetic variability for the traits GM, SD, LC, PD, SPAD and EB at the $1 \%$ and $5 \%$ levels by F-test (Table 1), demonstrating the possibility of selecting superior lines. The traits FT and ANT did not show significant differences, because the genotypes were under the same environmental condition. Steidle Neto et al. (2017) found different ANT content in lettuce genotypes grew in different environments.
Table 1. Mean squares, coefficients of variance and genetic parameters of variables analyzed in lettuce strains.

\begin{tabular}{cccccc}
\hline Characters $^{1}$ & TMS $^{2}$ & $\mathrm{H}^{2}(\%)$ & $\left.\mathrm{CVg}^{*} \%\right)$ & $\mathrm{CVg} / \mathrm{CVe}$ & $\mathrm{CV}(\%)$ \\
\hline GM & $7759.92^{* *}$ & 82.76 & 23.86 & 1.27 & 18.86 \\
SD & $0.15^{*}$ & 51.00 & 7.06 & 0.59 & 11.99 \\
LC & $50.82^{* *}$ & 91.42 & 18.42 & 1.88 & 9.77 \\
PD & $14.52^{* *}$ & 72.77 & 7.54 & 0.94 & 7.99 \\
FT & $2.30^{\text {ns }}$ & - & - & - & 8.40 \\
SPAD & $48.26^{* *}$ & 95.96 & 17.57 & 2.81 & 6.24 \\
ANT & $26.55^{\text {ns }}$ & - & - & - & 28.84 \\
EB & $410.23^{* *}$ & 92.60 & 13.81 & 2.04 & 6.76 \\
\hline
\end{tabular}

'GM= green mass (g); $\mathrm{SD}=$ stem diameter $(\mathrm{cm}) ; \mathrm{LC}=$ commercial leaves count; $\mathrm{PD}=$ plant diamete $(\mathrm{cm}) ; \mathrm{FT}=$ foliar temperature $\left({ }^{\circ} \mathrm{C}\right) ; \mathrm{SPAD}=\mathrm{SPAD}$ index; $\mathrm{ANT}=$ total of anthocyanin content $(\mathrm{mg} 100 \mathrm{~g}$ sample); $E B=$ early bolting (days after sowing). ${ }^{2}$ TMS: trait mean squares; $\mathrm{H}^{2}$ : coefficient of genotypic ermination; $\mathrm{CVg}$ : coefficient of genetic variation; $\mathrm{CV}$ : coefficient of environmental variation; $\mathrm{CV}$ : coefficient of variation; ***: significant at the level of $1 \%$ and $5 \%$ probability, respectively, by the F test; ns: not significant; -: non-significant variables in the analysis of variance.

The coefficients of variation (CV) fluctuated between $6.24 \%$ (SPAD) and $28.84 \%$ (ANT). The distribution of CV makes it possible to define ranges of values that guide the researcher regarding the credibility and validity of the experiments (Storck et al., 2011). In field experiments, CV value below $10 \%$ is considered low; medium, if between $10 \%$ and $20 \%$; high, if between $20 \%$ and $30 \%$; and very high, if above $30 \%$ (Pimentel-Gomes, 2009). In this study, $62.5 \%$ of the variables had low CV, demonstrating higher experimental precision and lower residual error value in the analysis of variance. Pinto et al. (2017) analyzing the development and production of curly lettuce found CV values close to those observed in this work for PD SD, LC and GM.

The coefficient of genetic variation $(\mathrm{CVg})$ values ranged between $7.06 \%$ (SD) and $23.86 \%$ (GM) (Table 1). The CVg is an important parameter, making it possible to know the extent of genetic variability in the population for all the studied traits (Leite et al., 2016). Assessing heat resistant lettuce progenies, Souza et al. (2008) reported the CVg values: PD 6.39\%; LC 6.97\%; leaf fresh weight 13.45\%; and EB $25.94 \%$. In this study, CVg values were $\mathrm{PD}=7.54 \% ; \mathrm{EB}=13.81 \%$ and $\mathrm{LC}=18.42 \%$ (Table 1). The difference in CVg values of both studies may be due to the genotypes and the conditions under which the experiment was conducted.

The CVg does not allow a complete estimate of the heritable variations and, therefore, it is necessary to estimate the coefficient of genotypic determination $\left(\mathrm{H}^{2}\right)$ or the trait heritability (Thakur et al., 2016). The $\mathrm{H}^{2}$ makes it possible to estimate the genetic gain to be achieved and to establish the best strategy of the breeding program (Baldissera et al., 2014). The values of $\mathrm{H}^{2}$ vary according to the variables analyzed, and the results over 0.70 are considered high (Ramalho et al., 2012).

The highest values of $\mathrm{H}^{2}$ were those of SPAD, EB, LC, and GM, which were 95.96\%, 92.60\%, 91.42\% and 
82.76\%, respectively, all considered high. Queiroz et al. (2014) and Silva et al. (2019) also found high heritability values $(95.65 \%$ and $96 \%$, respectively) for leaf count. The results suggested a successful perspective in phenotypic selection, confirmed by the $\mathrm{CVg} / \mathrm{CV}$ e ratio for the same variables, whose values were over one (Table 1). When the $\mathrm{CVg} / \mathrm{CV}$ e ratio is greater than or equal to one, the genetic variation available is the main responsible for the estimate variation of the experimental data (Leite et al., 2016).

The traits correlations contribute to the comprehension of the gene action. The results of this study showed that the genotypic correlation is greater than the phenotypic one. The traits that showed positive genotypic correlation were GM and PD (0.80), LC and EB (0.48), and SPAD and EB (0.44) (Table 2).

Table 2. Genotypic (G) and phenotypic (F) correlations in six characters evaluated in lettuce genotypes.

\begin{tabular}{|c|c|c|c|c|c|c|c|}
\hline Characters' & & GM & SD & $\mathrm{LC}$ & PD & SPAD & EB \\
\hline \multirow{2}{*}{ GM } & $G$ & 1.00 & 0.48 & -0.12 & $0.80^{++}$ & -0.29 & $-0.50^{+}$ \\
\hline & $\mathrm{F}$ & 1.00 & 0.38 & -0.03 & $0.77^{* *}$ & -0.26 & $-0.47^{*}$ \\
\hline \multirow{2}{*}{ SD } & G & & 1.00 & 0.15 & 0.50 & -0.16 & -0.30 \\
\hline & $\mathrm{F}$ & & 1.00 & 0.10 & 0.38 & -0.15 & -0.18 \\
\hline \multirow{2}{*}{ LC } & G & & & 1.00 & -0.02 & 0.30 & $0.48^{+}$ \\
\hline & $\mathrm{F}$ & & & 1.00 & 0.05 & 0.27 & $0.43^{*}$ \\
\hline \multirow{2}{*}{ PD } & G & & & & 1.00 & $-0.47^{+}$ & $-0.57^{++}$ \\
\hline & $\mathrm{F}$ & & & & 1.00 & $-0.40^{*}$ & $-0.49^{*}$ \\
\hline \multirow[t]{2}{*}{ SPAD } & $G$ & & & & & 1.00 & $0.44^{+}$ \\
\hline & $\mathrm{F}$ & & & & & 1.00 & $0.39^{*}$ \\
\hline \multirow[t]{2}{*}{$\mathrm{EB}$} & G & & & & & & 1.00 \\
\hline & $\mathrm{F}$ & & & & & & 1.00 \\
\hline
\end{tabular}

phenotypic correlation at 1 and $5 \%$ probability, respectively, by the $t$-test. ${ }^{+++}$Significant genotypic correlation at $1 \%$ and $5 \%$ probability, respectively, by the bootstrap method wht

The positive genotypic correlation between LC and EB and between SPAD and EB (Table 2) may help the selection process, because the selection of plants with higher LC and SPAD index allows to get plants more resistant to early bolting. The slight difference between the estimates of genotypic and phenotypic correlation provides the knowledge of how environmental factors impact the traits analyzed (Thakur et al., 2016). The results obtained for both correlations were close. Thus, the small difference between the values of genotypic and phenotypic correlations displayed by some of the variables analyzed in this study indicates that

environmental factors have minor impact on such traits. The selection on the basis of those traits will certainly improve lettuce's desirable agronomic characteristics. Comparable results were reported by Souza et al. (2008) and Thakur et al. (2016), who reported higher values of genotypic correlation of traits when compared to those of phenotypic correlation.

The direct selection provides maximum gains in a single trait that the breeder selects (Cruz, 2013; Cruz et al., 2014). In this study, the direct selection provided individual gains bigger than those of the indirect selection (Table 3).

Table 3. Selection gain estimates (SG\%) obtained for six evaluated characters, by direct selection (values in bold) and indirect in lettuce genotypes.

\begin{tabular}{ccccccc}
\hline Characters $^{\prime}$ & \multicolumn{7}{c}{ SG (\%) } \\
\cline { 2 - 7 } & GM & SD & LC & PD & SPAD & EB \\
\hline GM & $\mathbf{2 1 . 8 4}$ & 10.6 & 0.03 & -12.36 & -1.42 & -12.15 \\
SD & 1.34 & $\mathbf{4 . 9 0}$ & -0.21 & -0.96 & 0.64 & -1.39 \\
LC & 1.45 & 1.59 & 18.17 & -2.30 & 8.40 & 9.25 \\
PD & 4.25 & 1.68 & -0.06 & -5.27 & -1.21 & -2.42 \\
SPAD & -3.17 & -1.69 & 7.64 & 6.04 & $\mathbf{1 6 . 1 5}$ & 5.46 \\
EB & -4.39 & -2.04 & 4.48 & 3.38 & 5.88 & $\mathbf{1 2 . 0 9}$ \\
\hline Total & 21.32 & 15.04 & 30.05 & -11.47 & 28.44 & 10.84 \\
\hline 'GM= green mass (g); SD= stem diameter (cm); LC = commercial leaves count; PD = plant diameter (cm); SPAD = SPAD index; EB = early bolting (days after sowing). Favorable \\
selection criteria: increase for GM, SD, LC, SPAD and EB and reduction for PD.
\end{tabular}

The biggest gains by means of direct selection were those of the variables GM (21.84\%), LC (18.17\%), SPAD (16.15\%) and EB (12.09\%). The trait SD showed the smallest individual gain $(4.90 \%)$ by direct selection (Table 3), which matched with its low CVg (7.06\%) (Table 1). The SD relates to the increase of plant lodging resistance
(Chen et al., 2014). The SPAD index is directly associated to the chlorophyll content in the plants leaves, which is positively related to plant photosynthetic capacity (Klooster et al., 2012; Son \& Oh, 2013; Cassetari et al., 2015), increasing productivity.

The LC direct selection provided indirect gains for 
GM (1.45\%), SD (1.59\%), SPAD (8.40\%), increased EB time (9.25\%) and reduced PD (-2.30\%) (Table 3). This was the best strategy of indirect selection, because LC reduced PD without negatively affecting the rest of the traits. In Brazil, as well as in the USA and Europe, people tend to consume packaged, processed lettuce leaves (Sala \& Costa, 2012). Thus, plants with higher commercial LC are preferable to meet such demand (Suinaga et al., 2013).

The early EB, induced by high temperatures of Brazilian summer, results in lettuce losses, causing raise to the prices and reduction to the supply. Lettuce is usually sold in plastic or wooden box, almost without any cooling method to maintain the produce quality (Sala \& Costa, 2012). Thus, plants with lower PD is preferable aiming at preventing quality damage e losses during storage process.

Different from direct selection, the selection indexes promote simultaneous selection by combining several traits, increasing the chances of success in breeding program (Cruz et al., 2014). Mulamba and Mock index and Subandi multiplicative index showed comparable results, as well as the biggest gains for LC (13.68\%), SPAD index (12.04\%), EB (6.11\%) and reduction for PD (-1.44\%). Both indexes also resulted in the highest total gain value $(30.42 \%)$ (Table 4$)$, besides selecting the same genotypes. The LC direct selection was similar to 70\% of the genotypes (UFU-206\#3\# 1\# 1; UFU-189\#3\#1\#1; UFU-197\# 1 \# 1; UFU-7\# 1 \#2\# 1; UFU-189\#3\#2\# 1; Uberlândia 10000, and UFU-189\#3\#4\#1) provided by the previous indexes (Table 5).

Table 4. Selection gain estimates (SG\%) obtained by the classic index proposed by Smith (1936) and Hazel (1943) (SH), Mulamba \& Mock (1978) (MM) ranks sum index, Willians base index (1962) (W), Subandi's multiplicative index (1973) (M) and index based on genotype-ideotype distance (Cruz, 2006) (GI) in 25 lettuce genotypes.

\begin{tabular}{|c|c|c|c|c|c|c|c|}
\hline \multirow{2}{*}{ Index } & \multicolumn{7}{|c|}{ SG $(\%)^{1}$} \\
\hline & $G M$ & SD & LC & PD & SPAD & $\mathrm{EB}$ & Total \\
\hline $\mathrm{SH}$ & 21.84 & 1.34 & 1.45 & 4.25 & -3.17 & -4.39 & 21.32 \\
\hline$M M$ & -1.07 & 1.10 & 13.68 & -1.44 & 12.04 & 6.11 & 30.42 \\
\hline W & 21.39 & 0.94 & 2.73 & 4.54 & -0.15 & -3.48 & 25.97 \\
\hline$M$ & -1.07 & 1.10 & 13.68 & -1.44 & 12.04 & 6.11 & 30.42 \\
\hline GI & -7.0 & -1.74 & -4.40 & -1.61 & -2.99 & 0.92 & -16.82 \\
\hline
\end{tabular}

Maciel et al. (2020) analyzed through univariate analysis the same germplasm bank featured in the present study. These authors observed the genotypes selected by the Mulamba \& Mock and Subandi indexes are among those that showed the best agronomic and nutritional characteristics.

Results from Terres et al. (2015), showed comparable genetic gains by means of selection indexes in potato hybrid populations. They reported that the total gain estimates were superior with Mulamba and Mock index and Subandi multiplicative index. Those indexes struck a balance in the distribution of selection gains for most of the lettuce genotypes assessed in this study.
SH index showed the biggest GM gain (21.84\%) (Table 4), result comparable to that of direct selection (Table 3). In second place, the W index caused GM to gain $21.39 \%$. Both indexes showed the second and third highest total gain: $21.32 \%$ and $25.97 \%$, respectively (Table 4). By contrast, both indexes showed negative gain values for SPAD traits (SH $-3.17 \%$ and $\mathrm{W}-0.15 \%)$ and EB traits (SH $-4.39 \%$ and $\mathrm{W}-3.48 \%$ ) (Table 4 ).

$\mathrm{SH}$ index selected $90 \%$ of the genotypes pointed by $W$ index (Table 5). The difference was that SH index selected the genotype UFU-125\#1\# 1\# 1, whereas W index selected UFU-189\#3\#2\#1.

Table 5. Indication of the top ten lettuce genotypes by the classic index proposed by Smith (1936) and Hazel (1943), Mulamba \& Mock's (1978) sum of ranks index, Willians base index (1962), multiplicative index of Subandi et al. (1973) (M), and index based on genotype-ideotype (GI) distance.

\begin{tabular}{|c|c|}
\hline Selection indexes & Selected lettuce genotypes \\
\hline $\begin{array}{l}\text { Direct selection for number of } \\
\text { commercial leaves }\end{array}$ & 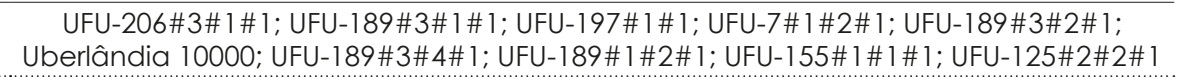 \\
\hline Smith (1936) and Hazel (1943) & 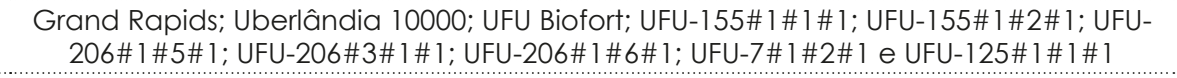 \\
\hline Willians (1962) & $\begin{array}{l}\text { Grand Rapids; Uberlândia 10000; UFU Biofort; UFU-155\# } 1 \text { \# } 1 \text { \# 1; UFU-155\# } 1 \text { \#2\# 1; UFU- } \\
\text { 206\# 1\#5\# 1; UFU-206\#3\# 1\# 1; UFU-206\# 1 \#6\# 1; UFU-7\# 1\#2\# } 1 \text { e UFU-189\#3\#2\#1 }\end{array}$ \\
\hline Mulamba \& Mock (1978) & 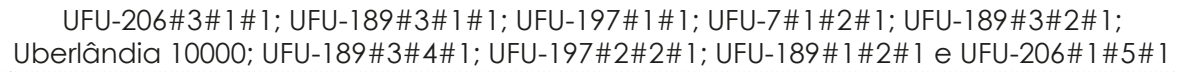 \\
\hline Subandi et al. (1973) & 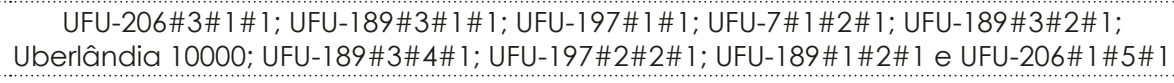 \\
\hline Genótipo-ideótipo & 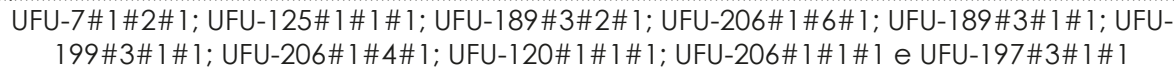 \\
\hline
\end{tabular}


Willians (1962) base index corresponds to that of Smith \& Hazel (1943), when phenotypic variances and covariances are determined mainly by genetic factors (Cruz et al., 2014). Analyzing Mulamba and Mock, Elston and Schwarzbach indexes applied to lettuce, Cândido et al. (2017) reported positive gains for the traits assessed by the first index. The authors attributed the positive result with Mulamba and Mock index to its strong correlation to the rest of the indexes and to the fact it can be easily measured. Such index has been suggested by other authors (Vasconcelos et al., 2010; Terres et al., 2015; Bizari et al., 2017).

Gl index showed positive selection gains only for EB $(0.92 \%)$ (Table 4). Fifty percent of the 10 selected genotypes were not found in the selection of the other indexes in this study: UFU-199\#3\#1\#1; UFU-206\#1\#4\#1; UFU-120\#1\#1\#1; UFU-206\#1\#1\#1 and UFU-197\#3\#1\#1. The lettuce line common to all selection indexes was UFU-7\# 1\#2\# 1 (Table 5). It shows that the same line was selected, regardless of the selection index. Dealing with strawberry hybrids, Vieira et al. (2017) found similarities in the genotypes selected by Mulamba \& Mock (1978) sum of ranks index, the genotype-ideotype distance-based index (Cruz, 2006), and Smith (1936) and Hazel (1943) traditional selection index.

\section{Conclusions}

Mulamba and Mock sum of ranks index and Subandi multiplicative index promoted the biggest total gains for the traits assessed. These indexes enabled positive gains for DC, NF, SPAD and EB, reducing the DP.

Both indexes were mutually consistent regarding the selected genotypes.

LC direct selection promoted the biggest SPAD and bolting indirect gains, reducing PD.

\section{Acknowledgments}

The authors thank the Federal University of Uberlândia, PROPP, CAPES, CNPq and FAPEMIG for their financial and administrative support.

\section{References}

Baldissera, J.N.C., Valentini, G., Coan, M.M.D., Guidolin, A.F., Coimbra, J.L.M. 2014. Genetics factors related with the inheritance in autogamous plant populations. Journal of Agroveterinary Sciences 13: 181-189.

Bizari, E.H., Val, B.H.P., Pereira, E.M., Mauro, A.O.D., UnêdaTrevisoli, S.H. 2017. Selection indices for agronomic traits in segregating populations of soybean. Revista Ciência Agronômica 48: 110-117.

Brzezinski, C.R., Abati, J., Geller, A., Werner, F., Zucareli, C. 2017. Produção de cultivares de alface americana sob dois sistemas de cultivo. Revista Ceres 64: 83-89.

Cândido, W.S., Tobar-Tosse, D.E., Soares, R.S., Santos, L.S., Franco, C.A., Braz, L.T. 2017. Selection of loose-leaf lettuce breeding lines based on non-parametric indexes. African Journal of Biotechnology 16: 1984-1989.

Cassetari, L.S., Gomes, M.S., Santos, D.C., Santiago, W.D., Andrade, J., Guimarães, A.C., Souza, J.A., Cardoso, M.G., Maluf, W.R., Gomes, L.A. 2015. $\beta$-carotene and chlorophyll levels in cultivars and breeding lines of lettuce. Acta Horticulturae 1083: 469-474.

Chen, C.C., Huang, M.Y., Lin, K.H., Wong, S.L., Huang, W.D., Yang, C.M. 2014. Effects of light quality on the growth, development and metabolism of rice seedlings (Oryza sativa L.). Research Journal of Biotechnology 9: 15-24.

Cruz, C.D., Regazzi, A.J., Carneiro, P.C.S. 2012. Modelos biométricos aplicados ao melhoramento genético. Editora UFV, Viçosa, Brazil. 514 p.

Cruz, C.D. 2013. Genes: A software package for analysis in experimental statistics and quantitative genetics. Acta Scientiarum. Agronomy 35: 271-276.

Cruz, C.D. 2006. Programa GENES: biometria. Editora UFV, Viçosa, Brazil. 382 p.

Cruz, C.D., Carneiro, P.C.S., Regazzi, A.J. 2014. Modelos biométricos aplicados ao melhoramento genético. Editora UFV, Viçosa, Brazil. 668 p.

Filgueira, F.A.R. 2013. Novo manual de olericultura: agrotecnologiamoderna na produçãoe comercialização de hortaliças. Editora UFV, Viçosa, Brazil. 421 p.

Francis, F.J. 1982. Analysis of anthocyanins. In: Markakis, P. (ed.) Anthocyanins as food colors. Academic Press, Cambridge, UK. p. 181-206.

Hazel, L.N. 1943. The genetic basis for constructing selection indexes. Genetics 28: 476-490.

Jacinto, A.C.P., Silveira, A.J., Castoldi, R., Maciel, G.M., Siquieroli, A.C.S., Mendonca, T.F.N., Souza, A., Marin, M., Braz, L. 2019. Genetic diversity, agronomic potential and reaction to downy mildew in genotypes of biofortified mini lettuce. Genetics and Molecular Research 18: 1-10.

Kim, D.E., Shang, X., Assefa, A.D., Keum, Y.S., Saini, R.K. 2018. Metabolite profiling of green, green/red, and red lettuce cultivars: Variation in health beneficial compounds and antioxidant potential. Food Research International 105: 361-370.

Klooster, W.S., Cregg, B.M., Fernandez, R.T., Nzokou, P. 2012. Growth and physiology of deciduous shade trees in response to controlled-release fertilizer. Scientia Horticulturae 135: 71-79.

Leite, W.D.S., Pavan, B.E., Matos Filho, C.H.A., Feitosa, F.S., Oliveira, C.B. 2016. Estimativas de parâmetros genéticos e correlações entre caracteres agronômicos em genótipos de soja. Nativa 3: 241-245. 
López, A., Javier, G.A., Fenoll, J., Hellín, P., Flores, P. 2014. Chemical composition and antioxidant capacity of lettuce: Comparative study of regular-sized (Romaine) and baby-sized (Little Gem and Mini Romaine) types. Journal of Food Composition and Analysis 33: 39-48.

Maciel, G.M., Gallis, R.B.A., Barbosa, R.L., Pereira, L.M., Siquieroli, A.C.S., Peixoto, J.V.M. 2019a. Image phenotyping of inbred red lettuce lines with genetic diversity regarding carotenoid levels. International Journal of Applied Earth Observation and Geoinformation 81: 154-160.

Maciel, G.M., Gallis, R.B.A., Barbosa, R.L., Pereira, L.M., Siquieroli, A.C.S., Peixoto, J.V.M. 2020. Image phenotyping of lettuce germplasm with genetically diverse carotenoid levels. Bragantia 79: 224-235.

Maciel, G.M., Siquieroli, A.C.S., Gallis, R.B.A., Pereira, L.M., Sales, V.F. 2019b. Programa de computador BG a Biofort. Depositante: Universidade Federal de Uberlândia. BR512019002403-6. Depósito: 01 feb. 2019. Concessão: 23 oct. 2019.

Mulamba, N.N., Mock, J.J. 1978. Improvement of yield potential of the Eto Blanco maize (Zea mays L.) population by breeding for plant traits. Egyptian Journal of Genetics and Citology 7: 40-51.

Pimentel-Gomes, F. 2009. Curso de estatística experimental. Editora FEALQ, Piracicaba, Brazil. 451 p.

Pinto, A.A., Santana, L.D., Camara, F.T., Rodrigues, W.Á.D. Costa, M.N.F., Penha Filho, N. 2017. Desenvolvimento e produção de alface crespa utilizando culturas para sombreamento lateral. Revista Verde de Agroecologia e Desenvolvimento Sustentável 12: 655-660.

Queiroz, J.P.S., Costa, A.J.M., Neves, L.G., Seabra Junior, S., Barelli, M.A.A. 2014. Estabilidade fenotípica de alfaces em diferentes épocas e ambientes de cultivo. Revista Ciência Agronômica 45: 276-283.

Ramalho, M.A.P., Abreu, A.F.B., Santos, J.B., Nunes, J.A.R. 2012. Aplicações da genética quantitativa no melhoramento de plantas autógamas. Editora UFLA, Lavras, Brazil. 522 p.

Resende, G.M., Costa, N.D., Yuri, J.E., Mota, J.H. 2017. Adaptação de genótipos de alface crespa em condições semiáridas. Revista Brasileira de Agricultura Irrigada 11: 1145-1154.

Rocha, D.S., Reed, E. 2014. Pigmentos naturais em alimentos e sua importância para a saúde. Journal of Environmental Science and Health 41: 76-85.

Sala, F.C., Costa, C.P. 2012. Retrospectiva e tendência da alfacicultura brasileira. Horticultura Brasileira 30: 187194.

Silva, O.M.P., Lopes, W.A.R., Nunes, G.H.S., Negreiros, M.Z. Sobrinho, J.E. 2019. Adaptability and phenotypic stability of lettuce cultivars in a semiarid region. Revista Caatinga 32: $552-558$.

Silveira, A.J., Finzi, R.R., Cabral Neto, L.D., Maciel, G.M.,
Beloti, I.F., Jacinto, A.C.P. 2019. Genetic dissimilarity between lettuce genotypes with different levels of carotenoids biofortification. Nativa 7: 656-660.

Smith, H.F. 1936. A discriminant function for plant selection. Annual of Eugenics 7: 240-250.

Son, K.H., Oh, M.M. 2013. Leaf shape, growth, and antioxidant phenolic compounds of two lettuce cultivars grown under various combinations of blue and red lightemitting diodes. HortScience 48: 988-995.

Sousa, L.A., Silveira, A.J., Maciel, G.M., Pires, A.C., Castoldi, R., Beloti, I.F. 2019. Agronomic potential of biofortified crisphead lettuce (Lactuca sativa) and its reaction to Root- knot nematodes. Australian Journal of Crop Science 13: $773-779$.

Souza, M.C.M., Resende, L.V., Menezes, D., Loges, V., Souto, T.A., Santos, V.F. 2008. Variabilidade genética para características agronômicas em progênies de alface tolerantes ao calor. Horticultura Brasileira 26: 354-358.

Steidle Neto, A.J., Moura, L.O., Lopes, D.C., Carlos, L.A., Martins, L.M., Ferraz, L.C.L. 2017. Non-destructive prediction of pigment content in lettuce based on visible-NIR spectroscopy. Journal of the Science of Food and Agriculture 97: 2015-2022.

Storck, L., Garcia, D.C., Lopes, S.J., Estefanel, V. 2011. Experimentação vegetal. Editora UFSM, Santa Maria, Brazil. 198 p.

Subandi, W., Compton, A., Empig, L.T. 1973. Comparison of the efficiencies of selection indices for three traits in two variety crosses of corn. Crop Science 13: 184-186.

Suinaga, F.A., Boiteux, L.S., Cabral, C.S., Rodrigues, C.S. 2013. Desempenho produtivo de cultivares de alface crespa. Boletim de Pesquisa e Desenvolvimento, n 89. Embrapa hortaliças, Brasília, Brazil. https://www.embrapa. br/busca-de-publicacoes/-/publicacao/956025/ desempenho-produtivo-de-cultivares-de-alface-crespa. $<$ Access on 22 Jan. 2020>.

Tassone, G.A.T., Nadaleti, D.H.S., Carvalho, G.R., Pereira, F.A.C., Andrade, V.T., Botelho, C.E. 2019. Simultaneous selection in coffee progenies of mundo novo by selection índices. Coffee Science 14: 83-92.

Terres, L.R., Lenz, E., Castro, C.M., Pereira, A.S. 2015. Estimativas de ganhos genéticos por diferentes índices de seleção em três populações híbridas de batata. Horticultura Brasileira 33: 305-310.

Tezza, G., Minuzzi, R.B. 2019. Caracterização da emissão foliar de cultivares de alface crespa em função da soma térmica. Journal of Environmental Analysis and Progress 4: 140-145.

Thakur, M., Kumar, R., Kumar, S. 2016. Studies on genetic variability, correlation and path analysis in lettuce (Lactuca sativa L.) under protected conditions. Journal of Applied and Natural Science 8: 1924-1930.

Vasconcelos, E.S., Ferreira, R.P., Cruz, C.D., Moreira, A., Rassini, J.B., Freitas, A.R. 2010. Estimativas de ganho 
genético por diferentes critérios de seleção em genótipos de alfafa. Revista Ceres 57: 205-210.

Vieira, S.D., Souza, D.C., Martins, I.A., Ribeiro, G.H.M.R., Resende, L.V., Ferraz, A.K.L., Galvão, A.G., Resende, J.T.V. 2017. Selection of experimental strawberry (Fragaria $x$ ananassa) hybrids based on selection índices. Genetics and Molecular Research 16:1-11.

Willians, J.S. 1962. The evaluation of a selection index. Biometrics 18: 375-393.

Conflict of Interest Statement: The authors declare that the research was conducted in the absence of any commercial or financial relationships that could be construed as a potential conflict of interest.

All the contents of this journal, except where otherwise noted, is licensed under a Creative Commons Attribution License attribuition-type BY. 